\title{
IN MEMORIAM: EVIE ALLISON ALLEN
}

Evie Allison Allen, whose translations from the Norwegian, Danish, and Swedish introduced English readers to important works on Whitman from the Scandinavian countries, died on 11 February 1988 in Westwood, New Jersey, after a long illness. She once explained her approach to learning foreign languages: "Get a grammar, a lexicon, read, and travel." Her translations of essays by Knut Hamsun, Johannes V. Jensen, and Roland Fridholm appear in Walt Whitman Abroad, edited by her husband Gay Wilson Allen (1955). But it was her translation of the Danish critic Frederik Schyberg's seminal study Walt Whitman $(1933 ; 1951)$ that would strongly influence Dr. Allen's approach to Whitman and in turn, through Allen's many works on the poet, a number of other scholars as well. In addition to her ease with Scandinavian languages, Mrs. Allen had mastered along the way what she once quietly termed "the usual languages"-French, German, Spanish, and Italian.

Mrs. Allen was born on 17 September 1897 in Piedmont, Alabama. She attended the Women's College of Alabama, in Montgomery, graduating in three years, in the class of 1917. After finishing the Atlanta Library School (later part of Emory University), she served as a librarian at Converse College, Spartanburg, South Carolina, and later in the public library system in Durham, North Carolina. In recent years, she "helped out," as she once put it, in the local Oradell (New Jersey) Public Library.

Her "Check List of Whitman Publications 1945-1960" appeared in Walt Whitman as Man, Poet, and Legend, edited by Dr. Allen (1961); it forms a part of her comprehensive bibliography of works on Whitman, presently housed in several large cartons, which Dr. Allen has drawn on for his Whitman studies.

A high point of a visit to the Allens' home in Oradell was afternoon tea, which Mrs. Allen presided over with her customary warmth, grace, and wit. She liked a good laugh and had a sharp eye for the poseurs on the national scene-whose antics generally gave her one.

Dr. Allen's biography of Whitman The Solitary Singer $(1955 ; 1984)$ bears the dedication which sums up the essence of their devoted sixty-three years of marriage: "To Eve As Much Her Book as the Author's."

Arthur Golden 